\title{
Деятельность Управления Государственной Внутренней Политической Охраны по защите безопасности и суверенитета Тувинской Народной Республики (1925-1934 гг.)
}

\author{
Николай М. Моллеров \\ Тувинский институт гуманитарных и прикладных социально-экономических исследований \\ при Правительстве Республики Тыва, Российская Федерация
}

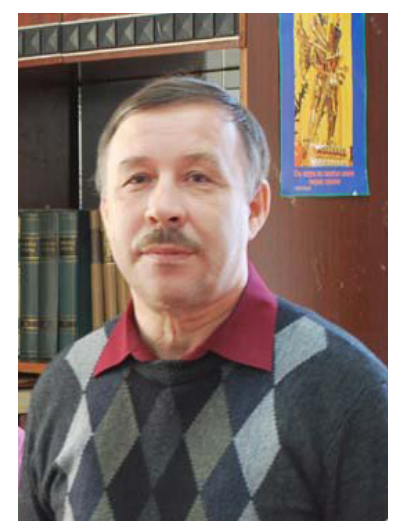

В статье анализируются конкретно-исторические условия и причины создания и деятельности службы безопасности в Тувинской Народной Республике - Управления Государственной Внутренней Политической охраны (УГВПО) в 1925-1934 г2. Источниками выступили материалы фондов Национального архива Республики Тыва, Государственного архива Красноярского края и др., которые вводятся в научный оборот впервые.

Непосредственным толчком для создания УГВПО послужило вооруженное выступление на Хемчике 1924 г. В его ходе была предпринята вооруженная попытка группы тувинцев, недовольных властью, ликвидировать государство и присоединить его к Монголии. На первых порах вопросами внутренней охраны молодого тувинского государства до создания специального органа занимался малочисленный правительственный отряд численностью в 40 солдат (циириков). Он был оформлен постановлением I Великого Хурала в 1923 г.

Служба безопасности ТНР строилась по образиу аналогичных служб в СССР и Монгольской Народной Республике. Как и там, основной задачей тувинских «чекистов» была борьба с контрреволюцией: предупреждение и ликвидация внутренних заговоров и вооруженных восстаний, предотвращение посягательств на безопасность и суверенитет THP.

В конце 1920-х г2. в деятельность УГВПО из СССР были привнесены преступные методы расследования и фабрикация дел. В 1934 г. УГВПО сменило Управление военной охраны страны УВОС, но изучение ее деятельности выходит за хронологические рамки настоящей статьи.

Ключевые слова: Тувинская Народная Республика; Тува; история Тувы; Управление государственной внутренней политической охраны; внутренние органы; государственная безопасность; суверенитет; политические репрессии

\section{Для цитирования:}

Моллеров Н. М. Деятельность Управления Государственной Внутренней Политической Охраны по защите безопасности и суверенитета Тувинской Народной Республики (1925-1934 гг.) // Новые исследования Тувы. 2020, № 3. C. 49-65. DOI: www.doi.org/10.25178/nit.2020.3.4

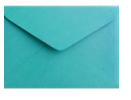

Моллеров Николай Михайлович - доктор исторических наук, главный научный сотрудник научно-исследовательской группы по истории Тувинского института гуманитарных и прикладных социально-экономических исследований при Правительстве Республики Тыва. Адрес: 667000, Россия, г. Кызыл, ул. Кочетова, д. 4 . Тел.: + 7 (394-22) 2-39-36. Эл. адрес: igi@tigpi.ru

MOLLEROV, Nikolai Mikhailovich, Doctor of History, Chief Research Fellow, Research Group on History, Tuvan Institute of Humanities and Applied Social and Economic Research under the Government of the Republic of Tuva. Postal address: 4 Kochetov St., 667000 Kyzyl, Russian Federation. Tel.: + 7 (394-22) 2-39-36. Email: igi@tigpi.ru ORCID ID: 0000-0002-7127-184X 


\title{
The Department of State Internal Political Security and its work to protect the security and sovereignty of the Tuvan People's Republic (1925-1934)
}

\author{
Nikolai M. Mollerov \\ Tuvan Institute of Humanities and Applied Social and Economic Research \\ under the Government of the Republic of Tuva, Russian Federation
}

\begin{abstract}
The article analyses specific historical conditions and reasons for creating a security service in the Tuvan People's Republic. Named the Department of State Internal Political Security, it was active in 1925-1934. Our study is based on documents from the National Archives of the Republic of Tuva, State archive of Krasnoyarsk krai and other archival collections. Some of the materials are presented here for the first time.

The direct reason for creating DSIPS was an armed revolt in Khemchik in 1924 - an attempt of Tuvans dissatisfied with the status quo to dismantle the state and join its territory to Mongolia. At first the internal security of a young Tuvan state was provided by a small troop of 40 soldiers (tsiriks). It was formed by the order of the Great Khural in 1923.

The security service of TPR functioned as its counterparts in the USSR and Mongolian People's Republic did. The primary task for Tuvan 'chekists' was to fight the counterrevolution, foil or quell internal plots and armed rebellions, and to prevent attacks on the security and sovereignty of the TPR.

At the end of 1920s, the DSIPS took a leaf from the GPU's book, introducing illegal investigation methods and fabrication of cases into its practice. In 1934 the Department of Military Security of the Country (DMSC) replaced DSIPS, but its work goes beyond the chronological framework of this article.
\end{abstract}

Keywords: Tuvan People's Republic; Tuva; Tuvan history; Department of State Internal Political Security; domestic authorities; national security; sovereignty; political repression

\section{For citation:}

Mollerov N. M. Deiatel'nost' Upravleniia Gosudarstvennoi Vnutrennei Politicheskoi Okhrany po zashchite bezopasnosti i suvereniteta Tuvinskoi Narodnoi Respubliki (1925-1934 gg.) [The Department of State Internal Political Security and its work to protect the security and sovereignty of the Tuvan People's Republic (1925-1934)]. New Research of Tuva, 2020, no. 3, pp. 49-65. (In Russ.). DOI: www.doi.org/10.25178/nit.2020.3.4

\section{Введение}

14 августа 1921 г. на Всетувинском учредительном хурале было провозглашено создание первого в истории тувинского государства, в октябре 1944 г. вошедшего в состав Советского Союза. Исторический опыт его самостоятельного существования всегда вызывал закономерный научный интерес. Вместе с тем, следует признать, что до настоящего времени многие аспекты исторического развития этого государства исследованы еще недостаточно.

Предметом изучения в настоящей статье является малоизученная история создания и становления в Тувинской Народной Республике (ныне Республика Тува) службы государственной безопасности. В научных работах по новейшей истории Тувы имеются лишь редкие упоминания о службе безопасности тувинского государства в связи с раскрытием различных вопросов. Более подробно в связи с освещением разных аспектов истории о службе безопасности рассказано во втором томе «Истории Тувы» (История Тувы, 2007). Пять лет назад Управление федеральной службы безопасности (УФСБ) России по Республике Тыва опубликовало юбилейное издание «На защите национальных интересов. 90 лет органам безопасности в Туве. 1925-2015 гг.» (На защите ..., 2015). В разделе «Из истории органов безопасности в Туве» этой книги приведены архивные документы, указывающие на время создания в Туве службы безопасности, раскрывающие ее цели и задачи, опубликованы редкие фотографии работников Управления Государственной Внутренней Политической охраны (УГВПО) (там же: 21, 23, 30-31). Однако скудость исторических материалов, использованных при написании раздела, предопределила его предельную лаконичность и породила много закономерных вопросов, оставшихся без ответов. Вместе с тем, характеризуя настоящее юбилейное издание, следует учитывать, что оно не преследовало научных целей и не проходило научное редактирование. 
Целью настоящей статьи стал анализ конкретно-исторических условий и причин создания и деятельности службы безопасности в Туве, первых тувинских и советских «чекистов» ${ }^{1}$, стоявших у истоков УГВПО в 1925-1934 гг. существования Тувинской Народной Республики. Как и в соседних СССР и МНР, основной задачей тувинских «чекистов» были: предупреждение и ликвидация внутренних заговоров и вооруженных восстаний, предотвращение посягательств на безопасность и суверенитет государства. Они принимали активное участие в отстранении от власти «правых», проведении классовых «чисток» и выселении из Тувы нелояльных к власти советских граждан, локализации и прекращении восстаний весны 1924 г. и начала 1930-х годов, антирелигиозной кампании, «раскулачивании», конфискации собственности и имущества феодалов и т. п.

Для раскрытия места и роли УГВПО в политической системе ТНР потребовались поиск и анализ новых архивных источников из фондов Национального архива Республики Тыва (НА РТ), Центра архивных документов партий и общественных организаций Национального архива Республики Тыва (ЦАДПОО НА РТ, бывшего партийного архива Тувы), Государственного архива Красноярского края (ГА КК) и двух центральных архивов: Архива внешней политики Российской Федерации (АВП РФ) и Российского государственного архива социально-политической информации (РГАСПИ), а также Научного архива Тувинского института гуманитарных и прикладных исследований при Правительстве Республики Тыва (НА ТИГПИ). Все упомянутые в статье материалы документов вводятся в научный оборот впервые.

Слабым местом в изучении проблемы было и остается отсутствие по объективным причинам материалов из архива ФСБ России по Республике Тыва. Из документальных источников НА РТ известно, что секретный архив при УГВПО был организован в соответствии с постановлением Совета Министров Тувинской Аратской Республики (ТАР, название тувинского государства в 1930-1941 гг. ${ }^{2}$ ) только от 7 апреля 1932 г., во время первой «волны» политических репрессий в Туве (НА РТ, ф. 92, оп. 1, д. 213, л. 5). Но и отложившиеся за последние три года деятельности УГВПО архивные материалы позднее были во многом утрачены. С высокой степенью вероятности можно предположить, что какая-то часть их после вхождения Тувы в состав советского государства в октябре 1944 г. могла перейти в ведомственные архивы службы безопасности российского или союзного уровней. Доступа к этим архивам ученые-тувиноведы пока не имеют. Порой невозможно восстановить даже инициалы первых «чекистов» Тувы, не говоря уже о биографиях.

Все же введение в научный оборот материалов вышеперечисленных доступных архивов, позволяет значительно расширить наше представление об УГВПО ТНР, стоявшем на защите государственности и суверенных прав тувинского народа.

\section{Вопросы государственной безопасности ТНР в 1921 - начале 1925 г2.}

Создание службы государственной безопасности в ТНР произошло позднее, чем в соседних странах - ВЧК в СССР (Булулуков, 2005; Из истории Всероссийской ..., 1958; Из истории спецслужб ..., 1997 ; Канчинский, 2005; Макаревич, 2002; Мозохин, 2004, 2005; Нежинский, 2004; Плеханов, 2006; Рыбалкин, 2002) и Государственной Внутренней Охраны (ГВО) в МНР (История Монгольской ... , 1954: 269), хотя внешние и внутренние угрозы существованию молодого и еще непризнанного государства были. В первую очередь это военная попытка установления контроля над Тувой белого генерала А. С. Бакича в начале декабря 1921 г. (Ганин, 2014) и вооруженный мятеж тувинцев на Хемчике весной 1924 г. с лозунгом присоединения к Монголии (История Тувы, 2007: 152-155). Промедление с созданием службы государственной безопасности было связано, прежде всего, с недостатком у тувинской правящей элиты опыта государственного строительства. Непризнание ТНР в качестве полноправного государства советским и монгольским правительствами в первой половине 1920-х гг. (Моллеров, 2010) не располагало к открытости и обмену с ними опытом по вопросам государственной безопасности. На первых порах вопросами внутренней охраны молодого тувинского государства до создания специального органа занимался малочисленный правительственный отряд численностью в 40 солдат (цириков) $)^{1}$, оформленный постановлением I Великого Хурала в 1923 г. (ЦАДПОО НА РТ, ф. 32, оп.1, д. 16, л. 23). Часть функций службы государственной безопасности возлагалась на МВД ТНР.

1 Слово «чекисты» взято в кавычки по причине спорности его прямого применения в отношении тувинских сотрудников УГВПО, а также в связи с тем, что ЧК (1918-1922) в рассматриваемое время уже не было.

Названия государства были закреплены в его конституциях: Танну-Тува улус - с 1921 г.; Танну-Тувинская Народная Республика - с 1924 г.; Тувинская Народная Республика - с 1926 г.; Тувинская Аратская Республика с 1930 г.; Тувинская Народная Республика - с 1941 г. (Конституции Тувы, 1999: 24-93). 
До создания УГВПО в Русской самоуправляющейся трудовой колонии (РСТК) в Туве был наработан определенный опыт в сфере обеспечения безопасности. Продолжающаяся в РСТК в новых формах политическая борьба между сторонниками и противниками советской власти побудила руководство РСТК наделить юридический отдел исполкома колонии функциями службы безопасности. На первых порах отдел возглавил Галак, который на 1 партийной конференции райбюро РКП(б) в Урянхае 4 августа 1922 г. доложил, что за пять месяцев с момента создания РСТК ${ }^{2}$, «благодаря принятым решительным мерам» (ЦАДПОО НА РТ, ф. 32, оп. 1, д. 16, л. 23), в колонии произошло сокращение преступности, особенно политической. Предметом особого внимания отдела юстиции с самого начала его деятельности становятся пленные из разбитого под Атамановкой (Суг-Бажи) отряда Бакича. Часть пленных райбюро РКП (б) с разрешения Реввоенсовета 5-ой Красной Армии оставило в Туве в качестве «спецов», из них многие были приняты на службу в отделы исполкома РСТК (ЦАДПОО НА РТ, ф. 32, оп. 1, д.18, л. 2). Эта категория населения РСТК в документах того времени именовалась «бакичане» (Моллеров, 2018).

В марте 1922 г. по просьбе райбюро РКП (б), адресованной начальнику особого отдела ВЧК А. Я. Берзину, в Туву прибывает Г. Скворцов, командированный Государственным политическим управлением (ГПУ) РСФСР для организации и ведения разведывательной деятельности. Предполагалось, что Г. Скворцов вскоре возглавит отдел юстиции и судебный подотдел исполкома РСТК (ЦАДПОО НА РТ, ф. 32, оп.1, д.18. лл. 50-54) Дальнейшая деятельность отдела юстиции до образования УГВПО связана с его именем.

Одним из практических результатов работы Г. Скворцова стало изучение обстановки в Туве и на ее южной границе, необходимое для принятия решения о выводе с тувинской территории советской воинской части. Он считал, что «ничего серьезного, что может угрожать колонии и политике РСФСР, нет» (ЦАДПОО НА РТ, ф. 32, оп. 1, д. 18, л. 102). Основываясь на данных и выводах Скворцова, советская воинская часть в начале 1923 г. была из Тувы выведена.

Но вскоре обострилась политическая обстановка в Советской колонии (как иначе называлась РСТК) в Туве. 18 апреля 1923 г. на заседании райбюро РКП (б) председатель исполкома РСТК Г. Я. Стрелков сделал доклад о политическом положении колонии, в котором отметил, что исполком РСТК на местах усилил осведомительный аппарат. Это позволило обнаружить в Верховье несколько беглых контрреволюционеров, которых поддерживали антисоветские элементы из местных колонистов. Он также сообщил: «Нащупаны нити контрреволюционной организации, разбросанной по колонии, не только среди русских, но частично замешаны и тувинцы. Силы, насколько удалось выяснить, незначительны, но есть опасность отдельных нападений. Меры предосторожности и слежки исполкомом приняты. Фракция (т. е. коммунисты в исполкоме. $-H$. М.) считает, что этой организации необходимо дать созреть и только тогда ее ликвидировать» (ЦАДПОО НА РТ, ф. 32, оп. 1, д. 24. лл. 42-43). Доклад приняли к сведению. Военному отделу исполкома РСТК предложили в случае тревоги привести в боевую готовность гарнизон г. Красного (ныне - г. Кызыл).

Активизация деятельности «элегестинской группы» Центрального комитета Тувинской НародноРеволюционной Армии (ЦК ТНРП) во главе с Оюном Курседи сопровождалась обострением политической борьбы в тувинском обществе и Туве в целом. Хорошо известно, что многие члены тувинского правительства в то время активно добивались упразднения ТНРП и роспуска ее ЦК, поскольку не усматривали пользы в существовании партий вообще. Временный роспуск ЦК встревожил руководство большевистской организации в Туве - райбюро РКП (б) по идейным соображениям. Кроме того, он означал бы упразднение партийной системы в Туве как таковой. Тем более что анархистская группа «Чудурук нам» («Сжатый кулак»), которую возглавлял Данзын-оол, была разогнана тувинским правительственным отрядом и вскоре перестала существовать. Как известно из истории Тувы, антипартийное решение правительства ТНР до конца выполнено не было (История Тувы, 2007: 138-139, 153). Райбюро РКП (б) в Туве через представительство НКИД РСФСР добилось восстановления ЦК ТНРП. Из информационного отчета райбюро РКП (б) за март-июнь 1923 г. мы узнаем, что отдел юстиции исполкома РСТК помимо внутриколонистских дел занимался расследованием убийства одного из представителей «элегестинской группы» Чуржапая. В отчете отмечалось: «Судя по материалам следствия, нити убийства, по-видимому, идут сверху» (ЦАДПОО НА РТ, ф. 32, оп. 1. д. 28, л. 16).

\footnotetext{
${ }^{1}$ Цирик (монг.) - военный, солдат.

${ }^{2}$ РСТК было юридически и политически оформлено в феврале 1922 г. См. об этом: Моллеров, 1989.
} 
Отдел юстиции исполкома РСТК во главе с Г. Скворцовым активно участвовал в локализации и «замирении» ${ }^{1}$ антигосударственного мятежа на Хемчике весной 1924 г. (в конфликте столкнулись интересы ТНР, МНР и СССР). В ходе этого восстания решался вопрос: быть или не быть самостоятельному тувинскому государству или Тува войдет в состав Монголии (История Тувы, 2007: 328-329). Именно знание ситуации изнутри позволило тувинским «государственникам» и советским работникам в Туве избрать правильную тактику в ликвидации вооруженного очага мирным путем. Прибывшая из Советского Союза делегация ЦИК СССР во главе с Я. Х. Давтяном имела в своем составе и работников ОГПУ.Да и сам Я.Х.Давтян, как известно, совмещалдипломатическуюдеятельностьс разведывательной ${ }^{2}$. В свое время он под псевдонимом «Давыдов» являлся первым руководителем Иностранного отдела ВЧК, созданного по известному приказу Ф. Я. Дзержинского № 169 от 20 декабря 1920 г. Отдел стал первым органом внешней разведки советского государства (Млечин, 2008: 6-7). Полученное от советского руководства «тувинское задание» Давтян успешно выполнил: вооруженный мятеж на Хемчике был прекращен без применения военной силы. Удалось не только отстоять государственную самостоятельность ТНР, но и заложить предпосылки для государственного признания ТНР со стороны СССР и МНР.

К недоработкам отдела юстиции следует отнести то, что заблаговременно предупредить вооруженное выступление на Хемчике не удалось. Серьезным недостатком работников отдела являлось слабое знание тувинского языка. Тот же Г. Скворцов за нежелание его изучать даже получил по партийной линии строгий выговор (ЦАДПОО НА РТ, ф. 32, оп. 1, д. 37, лл. 136, 156).

В 1920 -е гг. высшая мера наказания в колонии и Туве не применялась в связи «с местными условиями» (ЦАДПОО НА РТ, ф. 32, оп. 1, д. 37. л. 92). 18 августа 1924 г. райбюро поручило советскому консулу в Туве Ф. Г. Фальскому, в связи с раскрытием июльского контрреволюционного заговора в РСТК, запросить у ОГПУ Сибири и НКИД СССР разрешения применять в отношении колонистов высшую меру наказания. Но на закрытом заседании райбюро РКП (б) 13 октября 1924 г. Г. Скворцов доложил только о выселении из колонии политически неблагонадежных и участников июльского заговора, даже не упомянув о применении этой меры. Участников июльского заговора, во главе которого стоял бывший ординарец командира красных партизан в Туве С. К. Кочетова Николай Осинцев, он предложил отправить в ОГПУ СССР. Из «Доклада Чрезвычайному Полномочному Представителю СССР т. Давтяну для ЦК РКП (б) и Сибирского Крайкома РКП о работе райбюро РКП в Урянхае с 1921 г. по 1 августа 1924 г.», мы узнаем, что большинство участников этого заговора составляли «бакичане» (ЦАДПОО НА РТ, ф. 32, оп. 1. д. 37. л. 26). По докладу Г. Скворцова райбюро постановило: создать комиссию по выявлению политического лица подозреваемых, участников заговора с материалами и характеристиками отправить в ОГПУ СССР.

Таким образом, с 1921 г. и до начала 1925 г. - до создания в ТНР государственной службы безопасности - ее функции, как в РСТК, так и в Туве, выполнял юридический отдел исполкома РСТК. Он проводил расследование по делу об убийстве члена ТНРП Чуржапая, участвовал в мирном урегулировании вооруженного мятежа на Хемчике. Ликвидация мятежа, проходившего под лозунгом присоединения к Монголии, позволила сохранить национальное государство, отстоять его суверенитет. Это не было вмешательством во внутренние дела Тувы, поскольку конфликт носил международный характер, а юридический отдел РСТК действовал по просьбе тувинского руководства. Вместе с тем, данное положение свидетельствовало о том, что суверенитет ТНР еще не получил достаточного развития.

\section{УГВПО: создание и начало деятельности}

15 мая 1925 г. на заседании ЦК ТНРП было принято постановление о создании учреждения, которое первоначально назвали Управлением внутренней охраны страны (УВОС). Его возглавил заместитель председателя ЦК ТНРП Докпан. Райбюро РКП (б) в Туве адресовалась просьба о выделении для работы в УВОС инструктора. Начальнику нового учреждения и инструктору поручалось подготовить и представить в ЦК ТНРП проект секретного положения УВОС, а также подготовить предложения по другим аспектам его деятельности. В обсуждении вопроса участвовали председатель ЦК ТНРП Шагдыр, секретарь ЦК ТНРП Тумен-Баир и члены ЦК ТНРП: Балчин, Чамбал, Эренчин, Кечил-оол,

\footnotetext{
${ }^{1}$ Замирение означало урегулирование военного конфликта мирным путем без применения военной силы, путем ведения переговоров с повстанцами.

${ }^{2}$ Этот вопрос освящался автором в газетной статье: Моллеров, Н. М. Советский разведчик и дипломат Яков Давтян: тувинское задание // Слово-плюс (газета). 2009. № 3. 29 декабря. С. 4.
} 
Дондук, Сундуй, Дембирел, Самдан, Онгар-оол, Ензук, Седен-Соднам. От райбюро РКП (б) на заседании присутствовали: секретарь Я. С. Чугунов и члены - Д. С. Казначеев и П. С. Медведев (На защите ..., 2015: 20; ЦАДПОО НА РТ, ф.1, оп. 1, д. 158, лл. 22-25). 17 июня 1925 г. райбюро РКП (б) приняло решение о направлении в качестве советника в орган политической охраны ТНР Макара Барахтаева ${ }^{1}$, ранее работавшего в Министерстве юстиции ТНР. Все эти решения свидетельствовали о начале создания в ТНР службы безопасности.

На заседании ЦК ТНРП 1 июля 1925 г. вновь обсуждался этот вопрос. На нем было принято решение о создании Управления Государственной Внутренней Политической Охраны (УГВПО) и утверждены его положение и должностные оклады работников. Начальником управления остался Докпан, оперативным работником стал Дембирель, делопроизводителем - Тумен-Баир. В случае необходимости начальника замещал и подписывал за него документы Тумен-Баир (На перекрестке ..., 2014: 275; НА РТ, ф. 113, оп. 1, д. 7, лл. 19-20). Тогда же на заседании ЦК ТНРП была утверждена временная инструкция о работе УГВПО. Штатная численность сотрудников новой структуры, призванной защищать ТНР, первоначально составила всего 5 человек, на затем, судя по фотографии из юбилейной книги УФСБ России по Республике Тува, коллектив УГВПО заметно возрос (см. фото 1) Вскоре ОГПУ СССР направило в УГВПО ТНР в качестве инструктора Куприяна Ивановича Максимова ${ }^{2}$ На III Великом Хурале ТНР, проходившем 27 октября по 12 ноября 1925 г., УгВПО была оформлена законодательно. После Докпана ее возглавляли Адыг-Тюлюш Хемчик-оол, Сат Чурмит-Тажы, УлугТюлюш Бульчун, Оюн Падагандай и Оюн Сенгиижик.

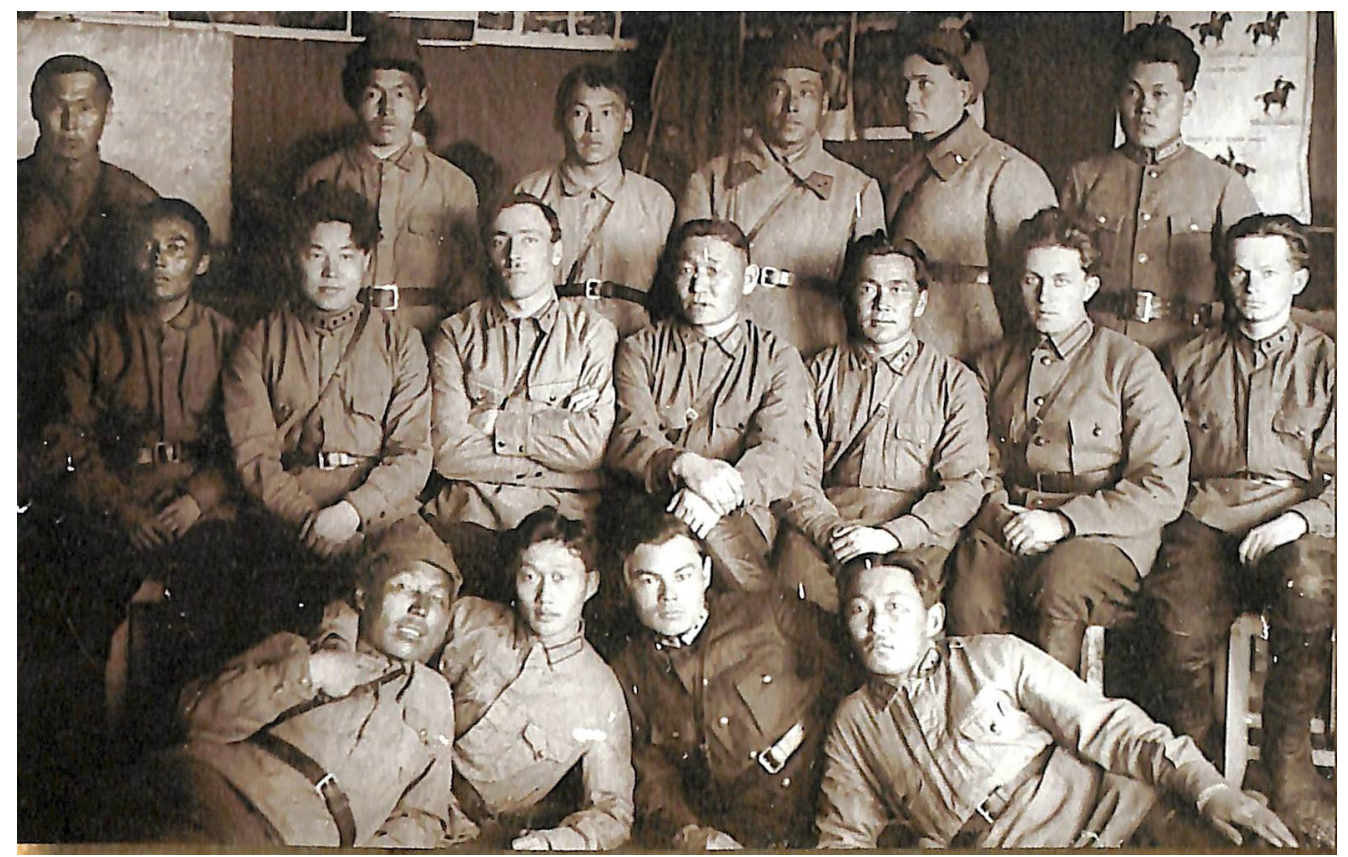

Фото 1. Коллектив УГВПО в 1925 2. (На защите ..., 2015: 21).

Photo 1. Personnel of the UGVPO (Department of State Internal Political Security) in 1925

(Na Zashchite, 2015: 21).

В фондах НА РТ хранится написанное от руки «Положение об Управлении Государственной Внутренней Политической Охраны Танну-Тувинской Народной Республики», которое не содержит ни даты, ни подписи. Возможно, это только проект позднее доработанного документа, а может быть и единственный экземпляр действующего положения УГВПО (фото 2). То, что он написан от руки, что на нем отсутствуют дата написания и имя автора (соавторов), можно вполне объяснить соображениями секретности. Но время и авторство документа можно установить, руководствуясь логикой, знанием истории и путем сопоставления с другими источниками.

${ }^{1}$ М. Барахтаев по национальности хакас, по социальному происхождению крестьянин (ЦАДПОО НА РТ, ф. 32, оп.1, д. 64. л. 77).

${ }^{2}$ Максимов Куприян Иванович - служащий из рабочих, 1899 г. р., член, ВКП (б) с 11 января 1928 г. (ЦАДПОО

НА РТ, ф. 32, оп.1, д. 52, л. 31). 


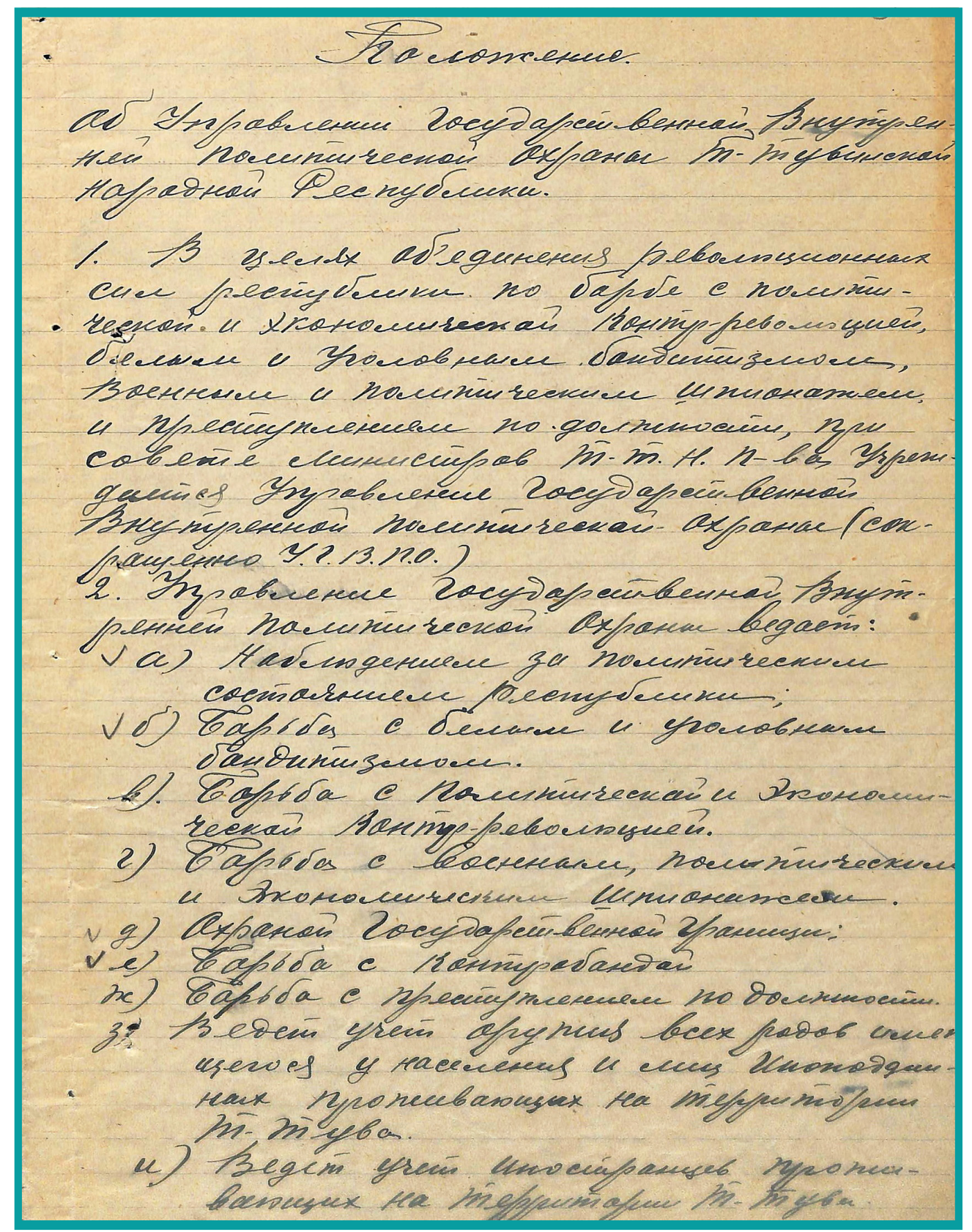

Фото 2. Первая страница рукописного Положения об УГВПО, предположительно 1925-1926 г2. (HA PT, ф. 104, on. 1, д. 1, л. 5).

Photo 2. Front page of the Statute of the UGVPO, manuscript, c. 1925-1926 (National Archives of the Republic of Tuva, f. 104, op. 1, d. 1, l. 5).

Так, в упомянутом документе республика названа «Танну-Тувинской», а такое название было закреплено в конституции 1924 г. и существовало до принятия конституции 1926 г. Значит, рукописное положение появилось в период с осени 1924 г. по осень 1926 г. Подготовительный этап создания УГВПО как раз попадает в эти хронологические рамки. Кроме того, процитированные выше документы о заседаниях ЦК ТНРП свидетельствуют, что подготовка положения возлагалась на начальника УГВПО и инструктора, которым в то время был прибывший из Москвы К. И. Максимов. Видимо, рукой последнего этот документ и был переписан после разработки и согласования, а образцами при его составлении вполне могли послужить положения ОГПУ СССР и Государственной политической охраны (ГПО) МНР. Утвердили же положение об УГВПО, как отмечалось, 1 июля 1925 г. То, что рукописный вариант мог быть действующим или был положен в основу действующего документа, свидетельствуют бесспорные признаки его практического применения, например, отсылки к нему в последующих 
документах. Так, пункт 9 рукописного положения гласит: «Надзор за законностью действий УГВПО осуществляется Советом Министров, и по уполномочию последнего председателем Совета Министров, пред которым УГВПО отчитывается путем ежемесячных письменных докладов» (НА РТ, ф. 104, оп. 1, д. 1, л. 7). Такие доклады (сводки) действительно в правительство периодически направлялись. Из анализа их содержания можно заключить, что практическая деятельность УГВПО вполне отвечала целям и задачам, изложенным в его рукописном положении. Так, в пп. 1-2 документа говорилось:

«1.... при Совете Министров Танну-Тувинского Народного Правительства создается Управление Государственной Внутренней Политической Охраны (сокращенно УГВПО). 2. Управление Государственной Внутренней Политической Охраны ведает: а) наблюдением за политическим состоянием республики; б) борьбой с белым и уголовным бандитизмом; в) борьбой с политической и экономической контрреволюцией; г) борьбой с военным, политическим и экономическим шпионажем; д) охраной Государственной границы; е) борьбой с контрабандой; ж) борьбой с преступлениями по должности; з) учетом оружия всех родов, имеющегося у населения и лиц иноподданных, проживающих на территории ТаннуТувы; и) учетом иностранцев, проживающих на территории Танну-Тувы; к) выполняет специальные задания правительства и ЦК Народной партии» (НА РТ, ф. 104, оп. 1, д. 1, лл. 5-5об.).

В соответствии с пунктом 4 «Положения» УГВПО наделялось судебными функциями; судебная коллегия получала право «определять наказание вплоть до высшей меры» (там же). При этом в примечании к данному пункту указывалось: «Постановления коллегии о высшей мере наказания приводятся в исполнение после санкции Совета Министров». Кассационные жалобы по высшей мере наказания также рассматривал Совет Министров и «решения последнего для УГВПО являлись окончательными» (там же: л. 6). Начальник УГВПО и его заместитель назначались Советом Министров, «с последующим утверждением Политбюро ЦК партии» (там же). Начальник УГВПО входил «в состав министров с правом решающего голоса» (там же).

Согласно пунктам рукописного «Положения» при УГВПО создавались две коллегии: судебная и административная. В состав судебной коллегии входили: начальник УГВПО, его помощник (он же секретарь коллегии), инструктор и представитель от ЦК ТНРП с правом решающего голоса. Кроме того, коллегия могла приглашать по необходимости и других представителей с правом решающего или совещательного голоса. В состав административной коллегии входили: начальник УГВПО, его заместитель и инструктор; она рассматривала и утверждала внутренний распорядок работы УГВПО и пограничный охраны на период свыше месяца.

Пунктом 10 этого документа устанавливалось, что УГВПО «в случае необходимости по делам оперативного характера вооруженной силой могло пользоваться в потребном ему количестве людей из кавэскадрона регулярной части тувинского правительства» (НА РТ, ф. 104, оп. 1, д. 1, л. 7об.). Кроме того, при УГВПО имелся отдел милиции. По данным за 1927 г., его сначала возглавлял Мунге, затем Падаган-оол, инструктором отдела был Черменев. Отдел также (п. 11) имел собственную смету, утверждаемую Советом Министров. Расходование средств на содержание своих работников, отмечалось в «Положении», УГВПО производит по смете; если же требуются дополнительные расходы, то «они производятся с разрешения Совета Министров» (НА РТ, ф. 104, оп. 1, д. 1, л. 7об.).

Одним из первых мероприятий УГВПО стала постановка на контроль всех иностранных фирм, торговых учреждений и предприятий в Туве, «входящих в состав государств, кои не имеют своих уполномоченных представителей в Туве» (НАРТ, ф. 113, оп. 1, д. 7, лл. 19-20). Так, по запросу УГВПО Таможенный отдел Минфина ТНР представил ему 14 августа 1925 г. список китайских фирм, находящихся на территории ТНР с указанием их названий, владельцев, расположения резиденций и отделений (На перекрестке ..., 2014: 275-276).

В 1926 г. начался перевод советских граждан в Туве под юрисдикцию тувинского государства, к тому времени признанного Советским Союзом (соглашение между ТНР и СССР от 22 июля 1925 г., см.: История Тувы, 2007: 334-335). Одним из важных шагов на этом пути стала передача в ведение ТНР вопросов обеспечения безопасности постоянно проживавших в Туве советских граждан. Перевод их под юрисдикцию ТНР сопровождался ликвидацией властных структур и организаций РСТК, массовым недовольством колонистов и требовал постоянного внимания со стороны служб безопасности РСТК и THP.

В период слияния РСТК с ТНР по источникам просматривается одновременное участие в заседаниях райбюро РКП(б) последнего заведующего юридического отдела исполкома РСТК Александра Лужбина и инструктора УГВПО ТНР Куприяна Максимова. После отбытия из Тувы Лужбина в обсуждении вопросов безопасности участвовал только инструктор УГВПО Максимов (ГАКК, p-49, оп.1, д. 525, л. 113). 
Постановлением тувинской правительства от 27 февраля 1927 г. новым начальником УГВПО «вместо отозванного для работы в Президиуме Малого Хурулдана Республики» Адыг-Тюлюша Хемчик-оола был назначен Сат Чурмит-Тажи (он же Председатель ЦКК ТНРП, член ЦК ТНРП) (РГАСПИ, ф. 495, оп. 1, д. 1, л. 95). Обнаруженные автором в РГАСПИ «Государственные информационные сводки» УГВПО за март и апрель 1927 г. наглядно демонстрируют, что принцип отчетности службы безопасности перед правительством в начальный период работы Чурмит-Тажи на этом посту исправно соблюдался.

С момента своего создания в середине мая 1925 г. и до конца 1920-х гг. УГВПО прошло стадию становления. Правовой основой его деятельности стало специальное положение, которым предусматривались: борьба с бандитизмом и контрреволюцией, отчетность перед правительством, контроль за иностранными гражданами в Туве, создание судебной коллегии. Высшая мера наказания в THР в 1920-е гг. не применялась, хотя вопрос о ее применении неоднократно поднимался во властных структурах Советской колонии и тувинского государства. С 1926 г. в ведение УГВПО перешла безопасность советских граждан в ТНР. Роль и значение УГВПО в государственной и общественной сферах жизни Тувы постепенно росли. 5 Великий Хурал ТНР (17 сентября 1927 г.) передал в ведение УГВПО армию (ЦАДПОО НА РТ, ф. 32, оп. 1, д. 80, лл. 213, 216).

\section{І буддийский съезд под контролем УГВПО}

В 1928 г. в Туве в качестве сотрудника УГВПО работал Генин-Дарма Нацов, 1901 г. р., бурят по национальности, кандидат в члены ВКП (б) с 1923 г. (ЦАДПОО НА РТ, ф. 32, оП. 1, д. 80, лл. 191-192). Это о нем так подробно рассказал в своей книге «Путешествие в азиатскую Туву» Отто Менхен-Хельфен (Менхен-Хельфен, 2014). От Генин-Дармы Нацова (не путать с представителем Коминтерна в Туве Сереном Нацовым) он узнал многое о тибетской медицине, от него услышал, что учения Будды и Ленина будто бы вполне согласуются между собой. Г.-Д. Нацов был одним из участников 1 буддийского съезда в Туве (1928 г.), на котором присутствовал не только как приверженец буддизма, но и по долгу службы в качестве сотрудника УГВПО.

1 Буддийский съезд, проходивший в марте 1928 г. в г. Кызыле, стал важным событием в жизни Тувы (История Тувы, 2007: 256-259). Следует подчеркнуть, что тема контроля УГВПО за работой съезда ранее в научных исследованиях не изучалась.

Информация о ходе съезда изложена в агентурной части доклада «О прошедшем 1 буддийском съезде в Тувинской Народной Республике», который был составлен под грифом «Совершенно секретно». Там, в частности, отмечалось, что делегаты съезда - ламы «интересовались, кто такие Маркс и Ленин, спрашивали о сути их учения, коммунистическом манифесте. В заключение ламы сказали, что учение Будды и учение Маркса и Ленина между собой тождественны, но разница только в том, что последнее видоизменено» (РГАСПИ, ф. 495, оп. 153, д. 28, л. 52). Как отмечено выше, эту точку зрения разделял и сотрудник УГВПО Г.-Д. Нацов.

Из материалов доклада мы также узнаем, что правительство ТНР готовило секретную операцию по возвращении отданного в 1921 г. Внешней Монголии Хазутского хошуна ${ }^{1}$. В нем говорилось:

«...В конце 1927 г. Правительство вполне серьезно стало говорить о возврате в свое подчинение дархат, т. е. проживавших в Хазутском хошуне тувинцев. ...Весной 1928 г. не позднее мая месяца предполагается командировать к дархатам 2-3 человек, которые едут под видом собирающих пожертвования лам с задачей узнать настроение дархат, ознакомиться с внутренним положением, управлением и рядом других вопросов. Командированные с этой целью должны всю свою миссию выполнить в 2-месячный срок. Во главе разведки намечается начальник УГВПО Чурмит-Тажи» (РГАСПИ, ф. 495, оп. 153, д. 28, лл. 64-65).

Общее руководство операцией возлагалось на главу правительства Дондука и его заместителя Талха-Сюрюна.

В докладе также сообщалось, что по ходу съезда делегаты раскололись на группы. Первая из них, возглавляемая Сульдум-Пунцуком, Сивеном, Араптаном и Шойданом, численностью до 10-13 человек выступала за удаление из монастырей женатых лам. Вторая из 10-12 человек (Баир, Баодын, Агван-Ширап и другие) с ними категорически не соглашалась. Оставшаяся часть делегатов в составе 7-9 человек соблюдала нейтралитет. Как у первой, так и у второй группы были покровители из членов Правительства. Первой группе покровительствовал председатель Совета Министров Куулар Дондук,

${ }^{1}$ Данная тема затрагивалась автором в СМИ в статье: Моллеров, Н. М. Этот странный «хазутский вопрос» в поисках ясности// Тувинская правда (газета). 15 сентября 2007 г. С. 5. 
второй - его заместитель Талха-Сюрюн (РГАСПИ, ф. 495, оп. 153, д. 28, л. 54). Далее говорилось, что «на съезде большинство высказывалось за удаление женатого ламства с хурэ, но когда разрабатывали резолюцию, то вопрос ...в самой резолюции нужной окраски не получил» (РГАСПИ, ф. 495, оп. 153, д. 28, лл. 66-68). На съезде был создан Президиум центрального органа духовного управления (ЦОДУ). Предполагалось, что он будет работать на постоянной основе. Местом его нахождения стал Кызыл. Предполагалось, что он «приступит к работе через 2 месяца после съезда, т. е. в конце мая месяца сего года» (РГАСПИ, ф. 495, оп. 153, д. 28, л. 54).

В агентурной части доклада давались характеристики главным участникам съезда. О Дондуке было сказано, что он «старается занять диктаторское положение», о Талха-Сюрюне, что «народ его хошуна выражает желание присоединиться к Монголии», о Буяне-Бадыргы, что он «во время восстания на Хемчике... принимал участие в его ликвидации, но в то же время имел связь с повстанцами», о Содноме, что «большим авторитетом среди населения пока не пользуется» (РГАСПИ, ф. 495, оп. 153, д. 28, л. 56).

Итак, І Буддийский съезд в Туве, созванный по инициативе бывшего ламы, главы правительства ТНР Куулара Дондука проходил с разрешения и под контролем УГВПО. И нельзя сказать, что опека «чекистов» над участниками съезда была жесткой. Если он проводился с целью вовлечения лам в созидательную государственную деятельность, то и участвовавший в его работе сотрудник УГВПО Г.-Д. Нацов был согласен с обновленцами в том, что учения Будды и Ленина близки. Однако убедительной победы над реакционной частью ламства, выступавшего за старые порядки, на съезде добиться не удалось.

\section{УГВПО в переломное время конца 1920-х - начала 1930 г2.}

В 1928 г. в Туву прибывает резидент ОГПУ Петр Ипполитович Пышкалло, сменивший в должности инструктора УГВПО К. И. Максимова. С именем П. И. Пышкалло связано такое важное историческое событие в Туве, как отстранение от власти «правого» руководства (История Тувы, 2007: 344, 345-349). В его деятельности наглядно проявились многие негативные черты советских работников НКвД, фабриковавших политические дела, применявших недозволенные методы следствия ради наград и быстрого продвижения по службе. Нельзя сказать, что все его предшественники в Туве были воплощением законности. Но нарушения закона в их работе случались редко, а в действиях Пышкалло прослеживается последовательно выстроенная система.

Из протоколов бесед полпреда СССР в ТНР А. Г. Старкова и представителя Коминтерна молодежи (КИМ) В. Мачавариани в декабре 1928 г. видно, что активное участие в смещении «правых» принимали бывший начальник УГВПО, председатель Малого Хурала Хемчик-оол и действующий начальник УГВПО, член Политбюро ЦК ТНРП Чурмит-Тажи. Сотрудник УГВПО П. И. Пышкалло, вместе с представителем Коминтерна С.А.Нацовым помогал «левым» В выработке политической платформы (РГАСПИ, ф. 533, оп. 8, д. 120, лл. 1-27) (фото 3).

Отмеченные выше способности Пышкалло нашли свое применение и в период свертывания деятельности отделения Госторга РСФСР в Туве

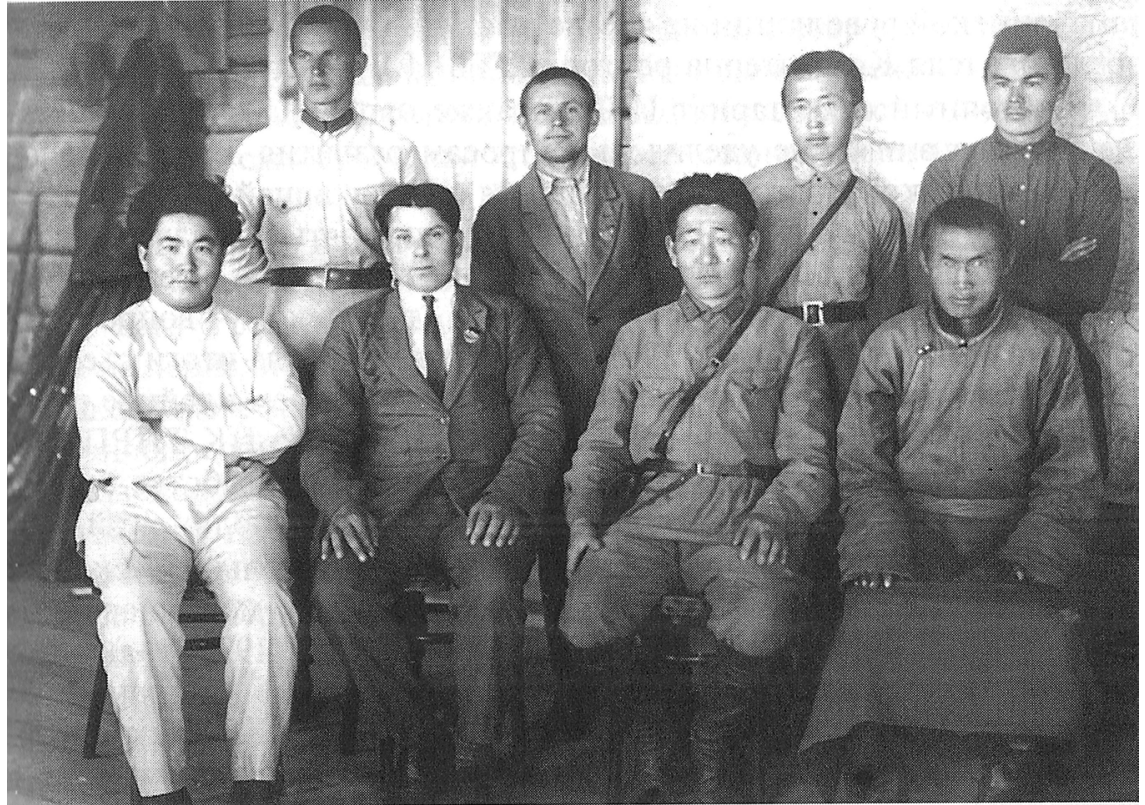

Фото 3. Работники УГВПО в 1927 г. Сидят (слева направо): Г. Д. Нацов, П. И. Пышкалло, Сат Чурмит-Тажы и Оюн Бадагандай. Фото из личного архива автора. Photo 3. UGVPO personnel in 1927.

Seated, left to right: G. D. Natsov, P. I. Pyshkalo, Sat Churmit-Tazhy and Oyun Badagandai. Photo from the author's personal archives. 
в 1931 г. Политически вопрос об уходе Госторга с тувинского рынка назрел и был между тувинским и советским руководством согласован. Однако, П. И. Пышкалло развернул целую компанию по дискредитации руководителя отделения Госторга РСФСР в Туве в лице О. О. Марка и других работников. Согласно отчета Пышкалло, в июле 1929 г. УГВПО проводило обыски на заимках Туранского района. «При обыске у Азютских кулаков, - писал Пышкалло, - были обнаружены огромные запасы дефицитных товаров (далемба, чай, сахар). В своих показаниях кулаки заверяли, что все эти товары они приобрели в Госторге» (НА РТ, ф. 92, оп. 1, д. 60, л. 4). Кроме того, создавалось ложное представление о конкуренции между Госторгом и Тувинценкоопом (Тувинским центральным кооперативом), в которой Госторг выглядел политически враждебным. В конце концов, О. О. Марку удалось избежать политических репрессий, но это стоило ему лечения расшатанных нервов (АВП РФ, ф. 153, оп. 6, д. 7, п. 2, лл. 9-10 об.).

К. И. Максимов, который не сработался с Пышкалло и называл его оболтусом, писал советскому полпреду в Туве А. Г. Старкову:

«Еще в бытность мою (в ТНР. - H. М.) он крайне неосторожно обращался с шифром. ...Имею вполне авторитетные сведения, что Пышкалло не сработался с тувинцами и не пользовался ни авторитетом, ни доверием с их стороны. Терпят его постольку, поскольку это необходимо и иного выхода нет....Безобразная перлюстрация корреспонденции, некоторые заявляют, что по три месяца не получали писем, тогда как раньше получали аккуратно. В числе жертв перлюстрации и я. Письма мои вскрываются самым безобразным образом, мало этого - конфискуются» (АВП РФ, ф. 153, оп. 6, д. 7, п. 2, л. 87).

По-видимому, новым работником УГВПО, сменившим Пышкалло, стал Болбар Дармаин, которого в архивных источниках называют «инструктором ГПУ» (АВП РФ, ф. 153, оп. 8, д. 8, д. 4, л. 4) и который имел отношение к переломным событиям начала 1930-х гг. в Туве: проведению антифеодальной революции, антирелигиозной кампании, коллективизации и расстрела представителей старой политической элиты ТНР. Имеется, в частности, упоминание в источниках об изъятии им у советника Тувинценкоопа Н. Х. Молчанова документа о доверии, выданного ему штабом партизанской армии ЩетинкинаКравченко в годы Гражданской войны. Позднее в годы пика политических репрессий в СССР и Туве Н. Х. Молчанов был репрессирован. На обложке подготовленной им второй части «Хрестоматии» по дореволюционной истории Тувы, фамилия и инициалы автора специально вымараны чернилами. В выходных данных опубликованого издания тираж не указан (Молчанов, 1935; фото 4).

Если в предшествующий период времени социально-классовая политика в ТНР жестко не проводилась, то в конце 1920 - начале 1930 г. произошло ее ужесточение. Более активно, без оглядки на закон начали действовать и работники УГВПО. Показательной в этом отношении является деятельность П. И. Пышкалло. Объектами внимания и преследования со стороны службы безопасности ТНР становятся советские дипломатические и хозяйственные работники в Туве, тувинские руководители.

\section{Межнациональные отношения, кадро- вый вопрос и служба безопасности}

В ноябре 1929 г. в Москву в отдел Дальнего Востока НКИД СССР на имя Л. М. Карахана из Тувы ушло письмо под грифом «Секретно» инструктора Тувинценкоопа Н. В. Дрелинга. Как свидетельствует пометка на письме, его копии были направлены во фракцию Правления Центросоюза, в Наркомат

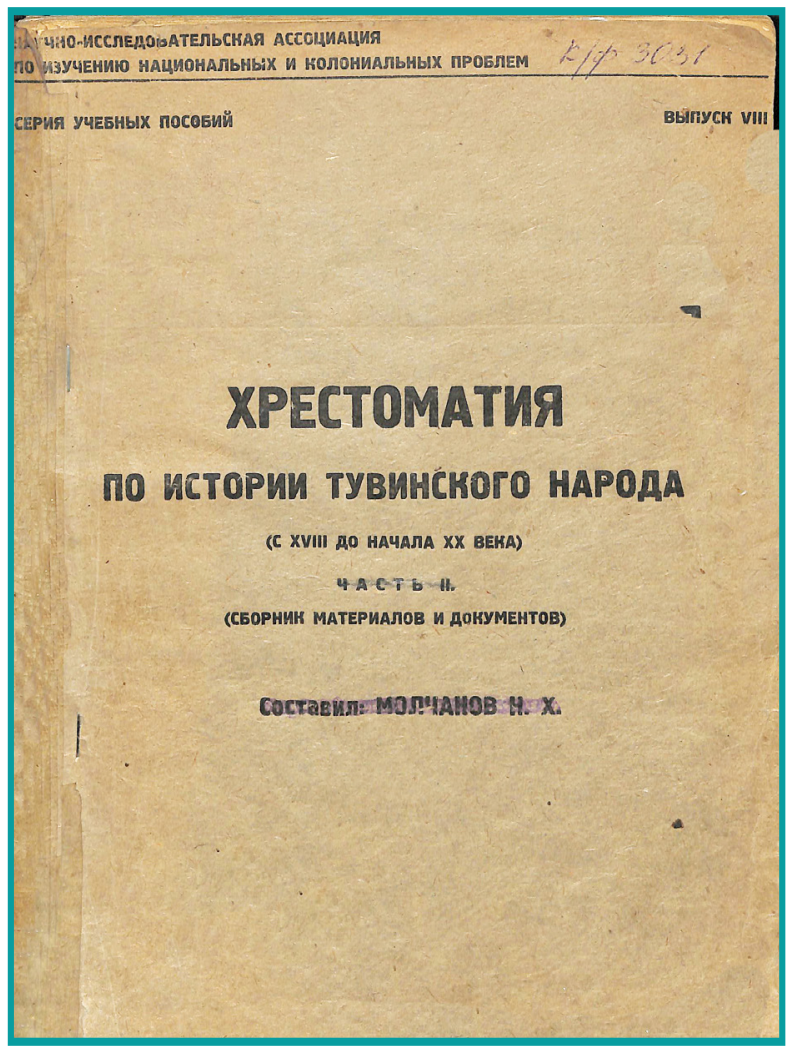

Фото 4. Обложка 2-й части «Хрестоматии», подготовленной Н. Х. Молчановым и изданной в 19352. (НА ТИГПИ, к/ф 3031).

Photo 4. Cover of the "Khrestomatia",

Pt. 2, compiled by N. Kh. Molchanov and published in 1935 (NA TIGPI, k/f 3031). 
рабоче-крестьянской инспекции (НКРКИ) СССР т. Ройзману, Центральную контрольную комиссию ВКП (б) т. Викману, Бюро заграничных ячеек (БЗЯ) ЦК ВКП (б) т. Магидову, контрразведовательный отдел ОГПУ СССР т. Тубола, иностранный отдел ОГПУ СССР т. Мессингу, исполком Коминтерна (ИККИ) т. Мифу (Пятницкому). По этим адресам можно понять, что за должностью инструктора Тувинценкоопа скрывалось лицо, пользующееся широким доверием советского руководства. Н. Л. Дрелинг в своем первом письме из Тувы охарактеризовал взаимоотношения между тувинцами и русскими, как очень проблемные, и привел в подтверждение своей оценки ряд примеров. Обобщив свои наблюдения, он сделал выводы, что «русские работники... допускают выпады против тувинских работников, которые ничем оправданы быть не могут» и что «работа по тувинизации аппарата почти не ведется...» (АВП РФ, ф. 153 , оп. 8, д. 8, п. 4, л. 154).

В РГАСПИ также хранится выписка из письма Дрелинга во фракцию правления Центросоюза СССР (копии данного письма были также направлены в НКИД Карахану, в ИККИ Пятницкому) от 4 февраля 1930 г. под грифом «Секретно». Дрелинг сообщал, что:

«решения последнего Тувинского партийного съезда (речь идет о VIII съезде ТНРП. - H. М.) об антирелигиозной пропаганде, борьбе с ламами, конфискации монастырского имущества на местах проводится довольно-таки коряво: на Джадане (в Чадане. - H. M.), например, арестовали всех лам и шаманов, потом пришлось их отпустить... начались разговоры о пересмотре границ с СССР, о появлении в Монголии Николая II и т. д. Все эти нездоровые настроения не подвергаются должному анализу и изучению. В некоторых пунктах к русским явно враждебное отношение (Шагонар). Никакой опасности для сегодняшнего дня все эти разговоры, конечно, не имеют, но все же всем этим настроениям надо уделять должное внимание. Тут же должен сообщить вам о какой-то «семейственности» на монгольской границе. Монголы путешествуют без всяких разрешений в Туву за хлебом, а тувинцы в Монголию за табаком. Где-то у черта на куличках на Терехуле (в сумоне Тере-Холь. - H. M.) еще до сих пор живут какие-то китайцы, собирающие с населения старые долги пушниной, последняя уже, по некоторым сведениям появилась на монгольском рынке. О Терехуле я сообщил в соответствующие организации....В ряде староверческих селений есть много злостных и опасных агитаторов, с которыми не ведется никакой борьбы» (РГАСПИ, ф. 495, оп. 153, д. 36, л. 1 об.).

Из вышесказанного в данном разделе следует, что русско-тувинские отношения и решение кадрового вопроса в Туве после прихода к власти «левых» находились под контролем советских «чекистов» и оценивались как проблемные. Обострялся вопрос о тувинизации органов власти и организаций ТНР. Однако первоочередным при осуществлении партийно-государственной политики все еще продолжал оставаться вопрос антифеодальной революции.

\section{Подавление волнений в период коллективизации и первая «волна» политических репрессий}

5 мая 1930 г. газета «Красный пахарь» писала: «В конце апреля месяца сего года органами УГВПО в колонии была обнаружена контрреволюционная кулацкая организация. Главари этой организации 26 апреля сего года были арестованы, часть организаторов, оставшихся на свободе, сгруппировав вокруг себя кулаков и недовольных классовой политикой власти, организовали в Шагонарском районе организацию, которая начала свою преступную деятельность».

О вооруженном выступлении в советской колонии в Туве полпред СССР в ТНР А. Г. Старков сообщил советскому руководству и лично Сталину. Одна из копий его письма была адресована и главе ОГПУ СССР т. Менжинскому. Полпред просил направить в Туву советскую воинскую часть. Однако ни в тот раз, ни позднее, когда произошли вооруженные выступления тувинцев, советские войска в Туву не вводились. ТНРА, ЧОН и УГВПО справились своими силами. Восстания, во многом спровоцированные перегибами при коллективизации, были подавлены. Наиболее активные участники этих восстаний были осуждены и расстреляны (История Тувы, 2007: 165-166, 191-194; НА РТ, ф. 93, оп. 1, д. 14, л. 1).

В начале 1930-х гг. в Туве проводилась конфискация скота и имущества феодалов. В постановлении объединенного заседания Президиума Малого Хурала и Совета Министров Тувинской Аратской Республики определялось: «имущество бывших феодалов и нойонов конфисковать» (РГАСПИ, ф. 495, оп. 153, д. 36, л. 13).

Всей работой по конфискации руководила комиссии под руководством бывшего начальника УГВПО, председателя Совета Министров ТАР Сата Чурмит-Тажи. В нее также входили представители ЦК ТНРП (Тока) и ЦК ТРСМ (Лопсан), руководитель ЦКК ТНРП Сандык, председатель Малого Хурала Хемчик-оол, председатель Колхозцентра Таня Камова (Сат) и представители от батраков, середняков и колхозников (РГАСПИ, ф. 495, оп. 153, д. 36, л. 13). Понятное дело, что комиссия в своей работе опиралась и на 
сведения УГВПО. В смету расходов УГВПО на 1929-1930 гг. было заложена немалая по тем временам сумма 44580 рублей, что также косвенно свидетельствует о заметном росте активности в деятельности этой организации в «переломное время» (АВП РФ, ф. 153, оп. 6, д. 7, п. 2, л. 24).

В начале 1930-х гг. по Туве прошла первая «волна» репрессий, жертвами которой стали «правые» руководители государства: Буян-Бадыргы, Дондук, Соднам и др. (История Тувы, 2007: 198-199). С приходом к власти «левых» влияние ТНРП возросло. В начале 1930-х гг. УГВПО помимо Совета Министров, отчитывалось и перед ЦК ТНРП, куда начальник УГВПО Сенгиижик направлял докладные записки. 15 августа 1932 г. он писал что «политическое и экономическое положение за последние два года значительно изменилось» в положительную сторону, но проведение мероприятий новой власти “сопровождалось упорным сопротивлением” феодалов и баев, вставших на путь скрытой, а местами (Тере-Холь сумон) открытой борьбы...» (РГАСПИ, ф. 495, оп. 153, п. 55, л. 31). Констатировался факт, что в 1930 г. в ТНР произошли крупные вооруженные выступления: хемчикское (март) и подхребтинское (апрель), в 1931 г. были раскрыты контрреволюционные повстанческие организации: тес-хемская (120 чел.) и подхребтинская (8 чел.). Также сообщалось, что в мае 1932 г. только в ходе операции в приграничной (южной) полосе было «вскрыто и ликвидировано» шесть контрреволюционных группировок и организаций против двух в 1930-1931 гг., из которых три были «явно повстанческого характера» (РГАСПИ, ф. 495, оп. 153, д. 55, л. 31).

В докладной записке подчеркивалось:

«Наиболее опасным элементом на данном отрезке времени является ламство, которое, формально будучи разгромлено, но не разбито идейно и не уничтожено физически (выделено мною. - H. M.), составляющее не менее 7-8\% к общему составу населения, с хурэ ${ }^{1}$ ушло в улусы и продолжают повседневно в скрытой форме вести свою контрреволюционную работу среди аратов. Вскрытие контрреволюционной организации и группировки в майскую (1932 г.) операцию показало, что основную организующую роль, идейным вдохновителем и застрельщиком этих организаций и группировок являлось ламство... которое продолжает жить чаяниями скорого возвращения в ТАР реакционера Дагдан-комбу, бежавшего из Тувы в 1924 г. и находящегося сейчас при Панчен-Богдо» (там же: л. 32).

Что касается светских феодалов, то они, согласно выводам УГВПО, «будучи подвергнуты внутрихошунному переселению, но, оставаясь неизолированными от основной аратской массы, продолжают иметь с последней связь и оказывать свое влияние» (там же: лл. 32-33).

«Вскрытая в августе месяце с. г. (по счету седьмая за 1932 г.) контрреволюционная группировка в Тусдаг сумоне (Улуг-Хемского хошуна), - говорилось в документе, - ориентацию контрреволюционных и правых элементов на контрреволюционеров и правых Монголии подтверждает. В приграничных районах всей южной полосы (Тере-Хольский, Ужарский, Качикский, Тусдагский, Каргы сумоны) ведется агитация за укочевку в Монголию. Некоторые из участников ликвидированной контрреволюционной группировки в Тусдаг сумоне уже начали переправлять свое имущество в Монголию, развертывая агитацию за это же среди основной аратской массы» (там же: л. 33).

В связи с «левым» курсом на ускоренное развитие ТНР по пути к социализму, предусматривавшим непопулярные меры по ликвидации феодалов как класса, гонениям на буддистов и шаманистов, сплошной коллективизации, началу политических репрессий роль УГВПО в ТНР возрастала. Были увеличены финансовые средства на ее содержание. УГВПО играло активную роль в конфискации феодальной собственности, обеспечивая агентурными ведениями Комиссию по конфискации, возглавляемую Сатом Чурмит-Тажи. УГВПО стало подотчетной не только перед правительством, но и перед ЦК ТНРП. Тувинские «чекисты» добывали разведданные в ходе подавления вооруженных восстаний в Советской колонии и тувинских хошунах, в том числе в пограничной тувинско-монгольской полосе. При их попустительстве, а возможно и участии, по Туве прокатилась первая «волна» политических репрессий. Расстрелы проводились без суда и следствия. В это время была задействована высшая мера наказания - расстрел, и были расстреляны тувинские государственные и партийные деятели.

\section{УГВПО: ужесточение контроля в сфере экономики}

На «экономическом фронте», по оценке УГВПО, также чувствовалась напряженность. В связи с этим отмечалась необходимость в «правильном руководстве» и «своевременных оперативно-профилактических мер на участках, где будут отмечаться расхлябанность, вредительство, происки классового врага...» (там же: л. 34).

\footnotetext{
${ }^{1}$ Хурэ (тув. хурээ) - буддийский монастырь, храм.
} 
В связи с пересмотром старого и введением нового политико-хозяйственного курса (тувинский вариант нэпа; История Тувы, 2007: 195-198) в 1933 г. в докладной записке УГВПО было отмечено: «Наличие в стране частного рынка, как следствие частно-капиталистических элементов, развивает последним до некоторой степени свободу действий, а отсюда на органы УГВПО накладывается необходимо сугубая революционная бдительность по охране некапиталистических элементов» (там же: лл. 34-35).

«Меч аратской диктатуры (выделено автором статьи. - Н. М.) над контрреволюционным элементом, говорилось далее, - глаза и уши ЦК АРП и Правительства и часовой, охраняющий мирный труд и революционные завоевания аратов - УГВПО, до сих пор в основном успешно справлялась с возложенными на него специальными задачами. ... Однако этап борьбы с открытой контрреволюцией пройден. Феодально-теократические контрреволюционные элементы, потерпев поражение в открытом бою, ушли в подполье, а это во многом осложняет борьбу. Отмечалось, что наличие средств и сил, имеющихся в распоряжении УГВПО в данное время, не обеспечивают полностью оперативно-профилактических мероприятий» (РГАСПИ, ф. 495, оп. 153, д. 55, л. 34).

В связи с усложнением условий работы УГВПО обратилось к ЦК ТНРП и правительству ТНР с просьбой:

«1. Дать конкретные политические установки, исходя из решений IX съезда АРП, ориентировав в основных задачах данного съезда.

2. Предоставить возможность укомплектовать аппарат УГВПО как качественно, так и количественно.

3. В обеспечение выполнения возлагаемых на УГВПо задач, УГВПО просит расходную смету довести до 113 тыс. руб., вместо 69 тыс. руб., одновременно приходную увеличить до 100 тыс. руб. вместо 45 тыс. рублей» (там же: л. 35).

Отсюда видно, что масштаб деятельности УГВПО и средства на ее обеспечение из года в год росли. В материалах 3-й сессии Малого Хурала ТАР, проходившей осенью 1933 г., в выступлениях ее делегатов, в частности, то и дело рефреном звучит мысль, что «отделы УГВПО в хошунах считают себя выше всех» (там же: л. 38). Так, делегат Пиринлей в связи с этим заметил, что местная власть имеет слабый авторитет, что его больше у УГВПО (там же: л. 36).

Еще большее влияние на судьбы граждан служба безопасности ТНР получила после реорганизации УГВПО в Военное управление охраны страны (ВУОС) летом 1934 г. В ее ведение перешли все силовые структуры: армия, милиция и даже добровольные Общества содействия обороне страны (ОСОС). В «Истории Монголии. XX век» упоминается, что в том же году подобное преобразование Сталин предложил МНР, порекомендовав обновленную структуру службы безопасности усилить (История Монголии, 2007: 100). Это делалось с целью сохранить за государством командные высоты в условиях легализации частной собственности. Возможно, что и Тува получила подобные рекомендации из Москвы. Дальнейшая история службы государственной безопасности ТНР лежит за хронологическими рамками настоящей статьи.

\section{Заключение}

Таким образом, служба безопасности ТНР, в начальный период своей деятельности известная как УГВПО, была создана после силовой попытки упразднения тувинского государства путем включения его в состав Внешней Монголии (затем МНР) и накануне дипломатического признания ТНР Советским Союзом. Ее структура и деятельность строились по образцу служб безопасности СССР и МНР. Как и там, основной задачей тувинских «чекистов» была борьба с контрреволюцией: предупреждение и ликвидация внутренних заговоров и вооруженных восстаний. Из СССР в МНР и ТНР порой направлялись похожие рекомендации. В начальный период деятельности УГВПО использовался опыт, наработанный юридическим отделом исполкома РСТК. К тому времени сотрудники отдела приняли активное участие в «замирении» вооруженного мятежа на Хемчике, в переводе советских граждан в Туве под юрисдикцию ТНР, включая и вопросы обеспечения их безопасности. Все 1920-е гг. в РСТК и ТНР высшая мера наказания (расстрел) не применялась.

С конца 1920-х гг. в деятельность УГВПО ТНР из СССР были привнесены преступные методы расследования и фабрикация дел. При этом на доказательность предполагаемых преступлений должного внимания не обращалось: следователи были заняты не восстановлением законности, а проведением политической кампании против «врагов народа». В начале 1930-х годов по Туве прошла первая «волна» политических репрессий. В спорах о главных виновниках трагических событий не следует забывать, что расстрелы производились с санкции Совета Министров ТНР, он же рассматривал кассационные 
жалобы по расстрельным делам. В исследованиях историков-тувиноведов внимание на это не обращается. УГВПО подчинялось поначалу только правительству, затем подчинение стало двойным - и Совет Министров, и ЦК ТНРП.

Роль и значение УГВПО в государственной и общественной сферах жизни Тувы постепенно росли. Историк Ю. Л. Аранчын в своей научно-публицистической статье «Долгий путь к правде» ${ }^{1}$ отмечал, что в 1930-е гг. в Туве прослеживается неуклонный рост влияния службы безопасности. Его наблюдение подтверждается и данными, приведенными в этой статье. Усиление УГВПО было тем более возможно, что оно функционировало в условиях неустоявшейся демократии, при сильном внешнем влиянии CCCP.

\section{Благодарности}

Благодарю к. и. н. Аяну Анай-ооловну Самдан за оказанную мне научно-методическую и научноорганизационную помощь.

\section{СПИСОК ЛИТЕРАТУРЫ}

Булулуков, Н. Ю. (2005) Правовое регулирование организации и деятельности органов государственной безопасности (1922-1934). М.: Академия федеральной службы безопасности. 194 с.

Ганин, А. (2014) Урянхайский поход Бакича // Родина. № 7, июль. С. 52-58.

Из истории Всероссийской Чрезвычайной комиссии. 1917-1921 гг. (1958) : сб. документов / сост. А. К. Гончаров и др. М. : Политиздат. 511 с.

Из истории спецслужб Бурятии (1997): Материалы научно-практической конференции, посвященной 80-летию ВЧК - ФСБ / общ. ред. В. И. Халанов, Б. В. Базаров. Улан-Удэ : ВСГАКИ. 102 с.

История Тувы (2007) / под общей ред. В. А. Ламина. Новосибирск : Наука. Т. 2. 430 с.

История Монгольской Народной Республики (1954) / гл. ред. Б. Д. Греков, С. А. Козин, А. А. Губер и др. М. : Издательство Академии Наук СССР. 422 с.

История Монголии. ХХ век (2007) / отв. ред. Г. С. Яскина. М. : ИВ РАН. 488 с.

Канчинский, О. (2005) Госбезопасность изнутри. Национальный и социальный состав. М. : Эксмо. 383 с.

Конституции Тувы (1999) : сборник к 55-летию принятия Тувы в состав СССР и РСФСР / сост. В. А. Дубровский. Кызыл : Тувинское книжное издательство. 216 с.

Макаревич, Э. (2002) Политический сыск. М.: Алгоритм. 430 с.

Менхен-Хельфен, О. (2014) Путешествие в азиатскую Туву // Урянхай. Тыва дептер : в 7 т. / сост. С. К. Шойгу. М. : Слово. Т. 6. Танну-Тувинская Народная Республика (1921-1944 гг.). 584 с. С. 220-261.

Млечин, Л. (2008) История внешней разведки. Карьеры и судьбы. М.: Центрполиграф. 510 с.

Мозохин, О. Б. (2004) ВЧК - ОГПУ на защите экономической безопасности государства и в борьбе с терроризмом. М. : Яуза ; Эксмо. 445 с.

Мозохин, О. Б. (2005) ВЧК - ОГПУ. Карающий меч диктатуры пролетариата. М. : Яуза ; Эксмо. 448 с.

Моллеров, Н. М. (1989) Истоки братства. Русская самоуправляющаяся трудовая колония в Тувинской Народной Республике. Кызыл : Тувинское книжное издательство. 143 с.

Моллеров, Н. М. (2010) Обращение НКИД РСФСР к тувинскому народу 9 сентября 1921 г. (новое прочтение) // Ученые записки ТИГИ. Кызыл. Вып. XXII. С. 136-144.

Моллеров, Н. М. (2018) После боя под Атамановкой: бакичане в Туве (1921-1932 гг.) // IV Центральноазиатские исторические чтения. Пространство культур: через призму единства и разнообразия. Сборник материалов научнопрактической конференции 20-23 сентября 2018 г. / отв. ред. 3. Ю. Доржу. Кызыл : Изд-во ТувГУ. 350 с. С. $237-241$.

Молчанов, Н. Х. (1935) Хрестоматия по истории тувинского народа (с XVIII до начала XX века): в 2 ч. М. : Научноисследовательская ассоциация по изучению национальных и колониальных проблем. Ч. 2. Сборник материалов и документов. 114 с.

На защите национальных интересов (2015) / предс. ред. совета О. Ф. Боломожнов. Абакан : ООО «Кооператив «Журналист». 144 с. $780 \mathrm{c}$

На перекрестке времени (2014) / гл. ред. А. М. Дугар-Сюрюн. Новосибирск: Сибирское книжное издательство.

Нежинский, Л. Н. (2004) В интересах народа или вопреки им? Советская международная политика в 1917-1933 годах. М. : Наука. 324 с.

${ }^{1}$ Аранчын, Ю. Л. Долгий путь к правде // Тувинская правда (газета). 1990, №№ 28, 29, 30, 35, 36, 38, 39, 41, 42, 43, $44,46,47,48,49,50,51$. 
Плеханов, А. М. (2006) ВЧК - ОГПУ в годы новой экономической политики 1921-1928. М. : Кучково поле. 702 с. Рыбалкин, Н. Н. (2002) Философия безопасности. М. : Олма-пресс. 253 с.

Дата поступления: 01.06.2020 2.

\section{REFERENCES}

Bululukov, N. Iu. (2005) Pravovoe regulirovanie organizatsii i deiatel'nosti organov gosudarstvennoi bezopasnosti (1922-1934) [Legal regulation of the organization and activities of state security agencies (1922-1934)]. Moscow, Akademiia federal'noi sluzhby bezopasnosti. 194 p. (In Russ.).

Ganin, A. (2014) Uriankhaiskii pokhod Bakicha [Bakich's Uriankhai campaign]. Rodina, no. 7, July, pp. 52-58. (In Russ.). Iz istorii Vserossiiskoi Chrezvychainoi komissii. 1917-1921 gg. (1958) [From the history of the All-Russian Extraordinary Commission. 1917-1921]: collection of documents / comp. by A. K. Goncharov et al. Moscow, Politizdat. 511 p. (In Russ.).

Iz istorii spetssluzhb Buriatii [From the history of the special services of Buryatia] (1997): Materials of a scientific and practical conference dedicated to the 80th anniversary of the Cheka-FSB / ed. by V. I. Khalanov and B. V. Bazarov. UlanUde, VSGAKI. 102 p. (In Russ.).

Istoriia Tuvy [The History Of Tuva] (2007): in 3 vols. / ed. by V. A. Lamin. Novosibirsk, Nauka. Vol. 2. 430 p. (In Russ.).

Istoriia Mongol'skoi Narodnoi Respubliki [History Of The Mongolian People's Republic] (1954) / ed. by B. D. Grekov, S. A. Kozin, A. A. Guber et al. Moscow, Izdatel'stvo Akademii Nauk SSSR. 422 p. (In Russ.).

Istoriia Mongolii. XX vek [History Of Mongolia. The twentieth century] (2007) / ed. by G. S. Yaskin. Moscow, IV RAN. 488 p. (In Russ.).

Kanchinskii, O. (2005) Gosbezopasnost' iznutri. Natsional'nyi i sotsial'nyi sostav [The state security from the inside. Ethnic and social composition]. Moscow, Eksmo. 383 p. (In Russ.).

Konstitutsii Tuvy [Constitutions of Tuva] (1999): a collection for the 55th anniversary of Tuva's accession to the USSR and RSFSR. Kyzyl, Tuvan book publishing house. 216 p. (In Russ.).

Makarevich, E. (2002) Politicheskii sysk [Political intelligence]. Moscow, Algoritm. 430 p. (In Russ.).

Menkhen-Khel'fen, O. (2014) Puteshestvie v aziatskuiu Tuvu [A journey to Asian Tuva]. In: Uriankhai. Tyva depter [Urianhai. Tuva notebooks]: in: 7 vol. / comp. by S. K. Shoigu. Moscow, Slovo. Vol. 6. Tannu-Tuvinskaia Narodnaia Respublika (1921-1944 gg.) [Tannu-Tuva People's Republic (1921-1944)]. 584 p. Pp. 220-261. (In Russ.).

Mlechin, L. (2008) Istoriia vneshnei razvedki. Kar'ery i sud'by [History of foreign intelligence. Careers and destinies]. Moscow, Tsentrpoligraf. 510 p. (In Russ.).

Mozokhin, O. B. (2004) VChK - OGPU na zashchite ekonomicheskoi bezopasnosti gosudarstva $i v$ bor'be s terrorizmom [Cheka - OGPU on the protection of the economic security of the state and in the fight against terrorism]. Moscow, Yauza, Eksmo. 445 p. (In Russ.).

Mozokhin, O. B. (2005) VChK - OGPU. Karaiushchii mech diktatury proletariata [Cheka - OGPU. The sword of vengeance of the dictatorship of the proletariat]. Moscow, Yauza, Eksmo. 448 p. (In Russ.).

Mollerov, H. M. (1989) Istoki bratstva. Russkaia samoupravliaiushchaiasia trudovaia koloniia v Tuvinskoi Narodnoi Respublike [The origins of the brotherhood. Russian self-governing labor colony in the Tuvan People's Republic]. Kyzyl, Tuvan book publisher. 144 p. (In Russ.).

Mollerov, N. M. (2010) Obrashchenie NKID RSFSR k tuvinskomu narodu 9 sentiabria 1921 g. (novoe prochtenie) [The Address of the NKID of the RSFSR to the Tuvan people, September 9, 1921: a new interpretation]. In: Uchenye zapiski TIGI. Kyzyl. Vol. XXII. Pp. 136-144. (In Russ.).

Mollerov, N. M. (2018) Posle boia pod Atamanovkoi: bakichane v Tuve (1921-1932 gg.) [After the battle of Atamanovka: Bakichans in Tuva (1921-1932 gg.)]. In: IV Tsentral'noaziatskie istoricheskie chteniia. Prostranstvo kul'tur: cherez prizmu edinstva i raznoobraziia [4th Central Asian readings in history. Space of cultures: through the prism of unity and diversity]. Proceedings of the conference on September 20-23, 2018 / ed. by Z. Yu. Dorzhu. Kyzyl, Izd-vo TuvGU. 350 p. Pp. $237-241$. (In Russ.).

Molchanov, N. Kh. (1935) Khrestomatiia po istorii tuvinskogo naroda (s XVIII do nachala XX veka) [Anthology on the history of the Tuvan people from the XVIII to the beginning of the XX century]: in 2 parts. Moscow, Nauchno-issledovatel'skaia assotsiatsiia po izucheniiu natsional'nykh i kolonial'nykh problem. Part 2. Sbornik materialov i dokumentov [Collection of materials and documents]. 114 p. (In Russ.).

Na zashchite natsional'nykh interesov [Protecting the national interests] (2015) / ed. O. F. Bolomozhnov et al. Abakan, $\mathrm{OOO}$ «Kooperativ «Zhurnalist». 144 p. (In Russ.). 
НОВЫЕ ИССЛЕДОВАНИЯ ТУВЫ

www.nit.tuva.asia

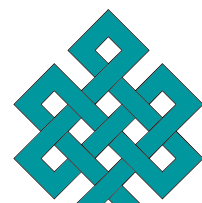

THE NEW RESEARCH OF TUVA

Na perekrestke vremeni [At the crossroads of time] (2014): a collection of archival documents and photo documents / eds.: A. M. Dugar-Surun et al. Novosibirsk, Sibirskoe knizhnoe izdatel'stvo. 480 p. (In Russ.).

Nezhinskii, L. N. (2004) Vinteresakh naroda ili vopreki im? Sovetskaia mezhdunarodnaia politika v 1917-1933 godakh [In the interests of the people or in spite of them? Soviet international politics in 1917-1933]. Moscow, Nauka. 324 p. (In Russ.).

Plekhanov, A. M. (2006) VChK - OGPUv gody novoi ekonomicheskoi politiki 1921-1928 [Cheka-OGPU in the years of the new economic policy 1921-1928]. Moscow, Kuchkovo pole. 702 p. (In Russ.).

Rybalkin, H. N. (2002) Filosofiia bezopasnosti [Safety philosophy]. Moscow, Olma-press. 253 p. (In Russ.).

Submission date: 01.06.2020. 